\section{Equity Financing of the Entrepreneurial Firm}

\author{
Frank A. Schmid
}

$\triangle$ $\mathrm{n}$ entrepreneur is an individual with a project blueprint and limited wealth. If launching the project requires expenses that exceed the entrepreneur's initial wealth, he needs outside financing. Entrepreneurs differ from "hired management" in that they are indispensable for the firm's day-to-day operations. This is because entrepreneurs add value to companies perpetually, rather than by handing over the project blueprints.

Outside financing is fraught with the problem of asymmetric information between the entrepreneur (who is a firm insider) and the (outside) investor. Asymmetric information between management and investor is considered the most significant problem in corporate finance. ${ }^{1}$ Typically, the problem of asymmetric information is modeled in finance literature as one that pertains to the use of free cash flow by management or to management's project choice. ${ }^{2}$ Asymmetric information about the use of free cash flow can take on a variety of forms. First, cash flow might be unobservable. In this case, the diversion of free cash flow for personal use by management goes unnoticed by the investor. If cash flows are unobservable, the outside equity holder has no bargaining power over the allocation of free cash flow to dividend payments. Second, management's use of free cash flow might be observable, but not verifiable. This is when the outsider can observe management directing free cash flow to its own benefit, but cannot verify these actions in court. Third, management's actions might be observable and verifiable, but compliance might not be enforceable. Examples of non-enforceability are cases where it is prohibitively costly for investors to go to court, or where court rulings are rendered worthless because the culprit is subject to limited liability or has limited wealth. ${ }^{3}$

In spite of the problems of asymmetric information outlined above, outside equity financing of the entrepreneurial firm has achieved a rapid increase over the past decade (see Figure 1). Venture capital funds, which finance privately held start-ups, raised

Frank A. Schmid is a senior economist at the Federal Reserve Bank of St. Louis. William Bock and Judith Hazen provided research assistance.

\section{Figure 1}

\section{Venture Capital Raised and Nasdaq IPOs}

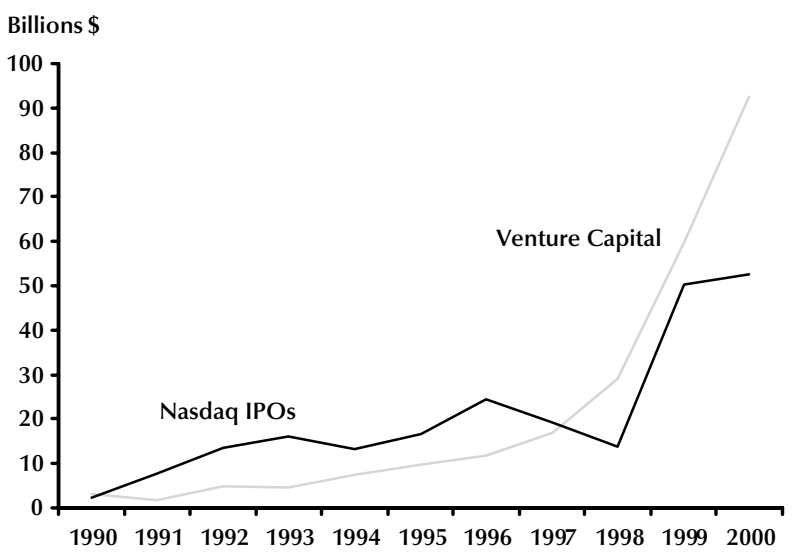

NOTE: Annual observations; last observation: 2000. SOURCE: Venture Economics \& National Venture Capital Association, <http://www.ventureeconomics.com>; Nasdaq, <http://www.marketdata.nasdaq.com $>$.

a record $\$ 92.3$ billion in 2000 . This is a thirty-fold increase relative to 1990. At Nasdaq, initial public offerings raised an all-time high of $\$ 53.6$ billion in 2000, which is 24 times as much as in 1990 .

This article analyzes equity financing of the entrepreneurial firm against the background of observable but non-verifiable cash flow. The study covers three organizational forms: the limited partnership, the private corporation, and the public corporation. The legal type of the firm determines the outside equity financing options that are available to the entrepreneur. By definition, initial public offerings are available to the (henceforth) public corporation only, whereas venture capital is possible for both the limited partnership and the privately held corporation.

The analysis shows that venture capital financing is superior to public offerings when the entrepreneur has low initial wealth relative to the size of the project and is equivalent otherwise. This result highlights the importance of private equity in financing entrepreneurial enterprises. The GrammLeach-Bliley Act of 1999 allows banks to expand

1 See Hart (1995), Jensen (2000), and Myers (2000).

2 See Zingales (2000).

3 For causes of lack of observability, verifiability, or enforceability and their consequences for contractual arrangements, see Hart (1995) or Milgrom and Roberts (1992). 
the scope of their activities in this arena. The law allows financial holding companies to provide equity financing to nonfinancial firms for up to ten years. In particular, the act defines a framework in which financial holding companies can sponsor private equity funds that provide venture capital to entrepreneurial firms. While it is not the purpose of this article to study the consequences of the GrammLeach-Bliley Act on venture capital financing, the analysis suggests that venture capital is a significant financing instrument. The Gramm-Leach-Bliley Act helps improve the supply side in the venture capital market by broadening the spectrum of institutions that are allowed to provide private equity to firms that do not (or not at this stage) seek to raise capital in an initial public offering.

The following analysis uses a simple model of the entrepreneurial firm as proposed by Myers (2000). While the analysis of the limited partnership draws heavily on Myers, the examination of the corporation differs from Myers most significantly in its simplicity and its focus on the most basic differences among the organizational forms. The model shows that private corporations face less stringent financing constraints than limited partnerships or public corporations. The result emphasizes the importance of the private corporation as a legal form. While the model helps explain the choice of the legal form by the entrepreneur, it cannot explain transitions among legal forms. For instance, the analysis offers no insights into why and when a private corporation might go public.

\section{A BRIEF LITERATURE OVERVIEW}

The literature on financing the entrepreneurial firm is diverse. This is because the characteristics that define the entrepreneurial firm are multifold. Moreover, some of these characteristics are not unique to the entrepreneurial firm but hold for other companies as well. In the following we briefly describe six major economic problems associated with financing the entrepreneurial firm that have been dealt with in finance literature.

First, there is the problem of project choice or, synonymously, asset substitution. If the entrepreneur holds the equity and the outsider holds the debt, the insider has an incentive to choose excessively risky projects. This is because the debt holder shares the downside risk, but not the upside risk. By increasing project risk, the entrepreneur can shift part of the additional risk to the debt holder. The classic study in this area is Jensen and Meckling
(1976). Note that the problem of asset substitution is not confined to the entrepreneurial firm. For instance, hired management of publicly traded firms might acquire stock or stock options in the firm as part of its compensation package.

Second, there is the problem of private control benefits. Management might take pleasure in being in control of the operations. The total value of the firm consists of its "social value," which is its fair market value, and the "private value," which is the value of the management's control benefits. The distinction between private and social values is important when it comes to the allocation of control rights between management and outside shareholders. Two seminal studies in this area are Grossman and Hart (1988) and Harris and Raviv (1988). For a textbook treatment, see Hart (1995). Note that private control benefits are not confined to the entrepreneur, but can apply to hired management as well.

Third, there is the problem of managerial entrenchment. Managerial entrenchment is not confined to the entrepreneurial firm, but might hold true for the firm with hired management as well. On one hand, the higher the fraction of equity owned by management, the closer the interests of management might be aligned to the interests of the outside shareholders. On the other hand, the more voting power management has, the more insulated it is from the disciplining forces of the market for corporate control. Entrenchment allows management to employ corporate resources for private benefits, for instance, through empire building or consumption of perquisites. Morck, Schleifer, and Vishny (1988) and McConnell and Servaes (1990) provide empirical evidence for managerial entrenchment. Zwiebel (1996) shows in a theoretical model how entrenched management can employ dividend payments as a means of committing to paying out free cash flow and keeping outside investors from intervening.

Fourth, free cash flow might be non-verifiable. When free cash flow is non-verifiable, the insider has the opportunity to divert it to consumptive use, for instance, by financing perquisites. Again, this problem is not confined to the entrepreneurial firm. On the other hand, non-verifiability of cash flows is seen as a significant problem in corporate finance and it earns considerable attention in finance literature. One thread of literature analyzes the role of debt as a way of forcing management to pay out free cash flow. Hart (1995) summarizes this literature in 
a textbook treatment. Another thread of literature looks at the role of dividend payments as a device to discipline management by maintaining a sufficient level of debt. The aforementioned paper by Zwiebel (1996) fits into this category. Finally, a recent paper by Myers (2000) studies the role of dividend payments in an all-equity financed firm. He shows that dividend payments can be viewed as advance compensation on the outsider's equity investment. The dividend payment at the end of the fiscal year compensates the investor for the opportunity cost of capital that he incurs in the upcoming fiscal year.

Fifth, there is the problem of risk sharing. Entrepreneurs typically are risk-averse individuals who have most of their human capital and financial wealth invested in the firm. Outside equity is a means of sharing risk as it allows the entrepreneur to limit his exposure to the enterprise. For details, see a recent theoretical paper by Kirilenko (2001).

Sixth, there is the problem of asset complimentarity. In the entrepreneurial firm, management owns an asset that is complimentary to the firm's operating assets. This means that the entrepreneur's human capital and the operating assets are worth more in combination than in isolation. Complimentarity between the managerial asset and the operating assets is an attribute that is confined to the entrepreneurial firm. While hired management is dispensable, the entrepreneur is not. Myers (2000) briefly discusses this point.

\section{A SIMPLE MODEL OF THE ENTREPRENEURIAL FIRM}

In the following analysis, the entrepreneur is defined as a person who owns human capital that is complementary to the operating assets of a firm (a "project"). As mentioned above, assets are complementary if they are more valuable when used in combination than in isolation. ${ }^{4}$ The entrepreneur can add value to the firm only by being in control of the day-to-day operations. He is indispensable for the operations because of his unique inventive and managerial skills. As opposed to a hired manager, the entrepreneur cannot be removed from the firm without hurting the project's net present value (NPV) of continuation. To keep matters simple, we assume that removing the entrepreneur from the firm reduces the NPV of continuation to zero or, put differently, lowers the going concern value to the level of the liquidation value.
The need for outside financing arises from the entrepreneur's wealth constraint. In terms of the model, the entrepreneur's initial wealth, $w$, falls short of the investment needed to start up the firm, $\bar{K}$, which we assume to be exogenous. The amount $\bar{K}-\mathcal{w}$ needs to be financed by an (outside) investor. The liquidation value of the operating assets is observable, verifiable (at zero cost), and equal to $\bar{K}$ in every fiscal year. Because the operating assets do not depreciate, there is an infinite investment horizon. There is no uncertainty in the model.

The project generates perpetual free cash flow equal to

$$
y_{t}=y=(1+\kappa) \cdot r \cdot \bar{K}
$$

at the end of every fiscal year $t(t=1, \ldots, \infty)$, where $r$ is the marginal cost of capital (for the entrepreneur and the investor) and $\kappa>0$ captures the value that the entrepreneur adds continually to the firm through his human capital. The condition $\kappa>0$ implies that the project has positive NPV at the outset (i.e., the beginning of fiscal year 1), as well as positive present value (PV) of continuation at the end of every fiscal year. We assume that there are no (other) positive-NPV projects becoming available to the entrepreneur once the project has been started. Thus, there is no productive use for internally generated funds.

The fundamental problem of financing the entrepreneurial firm is the entrepreneur's ability to divert free cash flow. By virtue of being in control of the operations, the entrepreneur can route free cash flow into personal accounts (where it earns $r$ at the margin). The amount of free cash flow that the entrepreneur diverts in fiscal year $t$ is denoted $Z_{t}$. Because all fiscal years are identical, we can write the following:

$$
Z_{t}=Z \text { for all } t, t=1, \ldots, \infty .
$$

We assume that while cash flows are observable (at zero cost) to outside investors, they are not verifiable (or verifiable only at prohibitively high costs). Were the project's cash flows verifiable (at zero cost), the problem of asymmetric information in financing the entrepreneurial firm would not exist. Because the entrepreneur would be able to commit to dividend payments, any positive-NPV project would be financed. However, with cash flows being non-

\footnotetext{
4 See Hart (1995) for details on asset complementarity and its implica-
} tions for firm organization. 
verifiable, the entrepreneur's inability to commit to future dividends leads to underinvestment. We will show that for sufficiently low levels of initial wealth, $w$, or, equivalently, sufficiently low levels of project profitability, $\kappa$, there are positive-NPV projects that are not undertaken.

The investor can provide outside financing through debt or equity. In this article, only equity financing is considered. 5 The firm may be organized into a limited partnership or a corporation. The corporation may be private or public. Limited partnerships and private corporations tend to have few equity holders, with the entrepreneur being one of them. The public (traded) corporation is typically modeled in finance literature as a corporation with dispersed equity holders. The outside investor, in this case, is a multitude of small shareholders whose subjective probabilities of being pivotal to corporate decisionmaking may be viewed as zero. For simplicity, we assume that, in the limited partnership and the private corporation, the firm outsider is a single investor (or, equivalently, a group of block holders who act as a single investor).

In the next section, the problem of equity financing is analyzed for the limited partnership. In subsequent sections the firm is modeled as either a private or a publicly traded corporation. The analysis shows that the legal form is critical for the degree of bargaining power the parties have over the fiscal year's free cash flow, once the parties are invested. It turns out that this ex post bargaining power is greatest for the outside investor in the private corporation. Consequently, the private corporation faces the least restrictive outside equity constraint.

\section{The Limited Partnership}

The limited partnership consists of a general partner - the entrepreneur - and one or more limited partners, which are the outside investors. For simplicity we represent the firm outsiders by a single investor (or, equivalently, a small set of block holders that act as a single investor). Because there is no uncertainty in the model, the difference between the general and the limited partners lies solely in the decision rights over liquidation, which is the only dimension of project choice in this model. Generally, in limited partnerships the outside investor can withdraw his funds (at the end of the fiscal year), but cannot demand liquidation of (all or parts of) the operating assets.

It is immaterial to the mechanics of the model whether partial liquidation is an option or whether the project can be liquidated in full only. If partial liquidation is possible, the periodic free cash flow of the project, $y$, decreases by the percentage of the liquidated assets. The assumption of full liquidation, on the other hand, would mean that any liquidation, even if in part, reduces $\kappa$ to zero, and with it the PV of continuation. 6

The (outside) investor contributes the fraction $x$ to the initial fixed investment, $\bar{K}$, while the entrepreneur contributes the fraction $1-x$ :

$$
x \bar{K}=\bar{K}-w \Leftrightarrow(1-x) \bar{K}=w .
$$

We define $\tilde{x}$ to be the fraction of equity held by the investor. This fraction $\widetilde{x}$ might be smaller than, equal to, or greater than the fraction of capital supplied by the investor, $x$, depending on whether the entrepreneur sells the equity at a premium, at par, or at a discount.

The partnership contract specifies that dividends are paid at the end of the fiscal year:

$$
d_{t}=d=y-z \text { for all } t, t=1, \ldots, \infty .
$$

Note that the fraction $1-\tilde{x}$ of the dividend payment goes to the firm insider.

Because all fiscal years are identical, we can write the PV of the future dividend stream at the beginning of any fiscal year as 7 :

$$
\frac{y-z}{r}=\frac{d}{r} \text {. }
$$

Investor's Continuation Constraint. The (outside) investor remains invested if the NPV of doing so is non-negative. In deriving this continuation constraint, we assume that the partnership contract allows the investor to withdraw his funds at the end the fiscal year, which means that there is no vesting period. Upon demand, the entrepreneur has to pay to the investor the cash equivalent of the fraction $\tilde{x}$ of the liquidation value of the operating assets. Note that if the investor withdraws his funds, the entrepreneur has no incentive to pay dividends for the respective fiscal year. The investor remains invested in the firm for (at least) one more

\footnotetext{
5 Hart (1995) presents an extensive treatment of debt financing of the entrepreneurial firm

6 The assumption of total liquidation has the advantage of being analogous to the assumption that a fixed amount of operating assets, $\bar{K}$, is needed to start the project.

7 Note that $\frac{d}{r} \equiv \sum_{t=1}^{\infty} \frac{d}{(1+r)^{t}}$.
} 
fiscal year if (and only if) the sum of this fiscal year's dividend payment and the PV of all future dividend payments is greater than or equal to the liquidation value. This yields the following continuation constraint for the firm outsider:

$$
\tilde{x} \cdot\left(d+\frac{d}{r}\right) \geq \tilde{x} \bar{K} \Leftrightarrow d+\frac{d}{r} \geq \bar{K} .
$$

In equilibrium, the investor's continuation constraint is satisfied at equality because the entrepreneur does not pay more in dividends than is needed to keep the outside equity capital in the firm:

$$
\tilde{x} \cdot \bar{K}=\tilde{x} \cdot\left(d+\frac{d}{r}\right) \Leftrightarrow d=\frac{r \bar{K}}{1+r} .
$$

Investor's Participation Constraint. The minimum level of dividend payments that satisfies the investor's continuation constraint need not fulfill the investor's participation constraint, i.e., his willingness to invest in the first place. For instance, if the outside equity were offered at par (which would imply $\widetilde{x}=x$ ), the investor's participation constraint would be violated. This is because, for $\tilde{x}=x$, the investor's capital contribution, $x \bar{K}$, exceeds the PV of the dividend stream, $x d / r$ :

$$
x \bar{K}>x \frac{d}{r}=x \bar{K} \frac{1}{1+r} .
$$

Because the entrepreneur cannot commit to dividend payments greater than what is needed to keep the outside equity capital in the firm, the investor is unwilling to finance the project in the first place. On the other hand, the entrepreneur can induce the investor to participate by issuing equity at a discount. Upon contributing $x \bar{K}$ in cash, the investor receives equity claims equal to $\tilde{x} \bar{K}$, $\tilde{x}>x$.

Note that, technically, the entrepreneur can issue equity at a discount by putting part of his own contribution, $w=(1-x) \bar{K}$, into equity reserves while selling the outside equity at face value.

The entrepreneur chooses the minimum $\tilde{x}$ that meets the investor's participation constraint:

$$
r x \bar{K}=\tilde{x} d\left[=\tilde{x} \frac{r \bar{K}}{1+r}\right] .
$$

This implies $\tilde{x}=x(1+r)$ and consequently:

$$
\tilde{x} d=x(1+r) d=x(1+r) \cdot \frac{r \bar{K}}{1+r}=x r \bar{K} .
$$

By issuing equity at a discount, the entrepreneur transfers the following amount to the investor at inception of the project:

$$
(\tilde{x}-x) \frac{d}{r}=(x[1+r]-x) \frac{d}{r}=r x \frac{d}{r}=x d .
$$

Technically, the entrepreneur can do this by transferring an amount equivalent to one dividend payment, $d$, to the reserves. The implied transfer to the investor at the amount $x \cdot d$ increases the return on the outsider's investment, $x \bar{K}$, by an amount sufficient to fulfill his participation constraint. At the same time, the investor's continuation constraint remains satisfied at equality.

In the Appendix we show that, in competitive capital markets, the investor cannot do better than break even. This implies that the investor has no incentive to renegotiate the partnership contract at the end of the fiscal year. By renegotiating the contract, the investor cannot improve his position beyond the break-even point, which is what fulfills his participation constraint.

Entrepreneur's Participation Constraint. Because the (outside) investor breaks even, the entrepreneur's participation constraint is equivalent to the NPV decision rule:

$$
\mathrm{NPV} \geq 0 \Leftrightarrow \frac{y}{r}-\bar{K} \geq 0 .
$$

For $y / r \equiv z / r+d / r$ and $\bar{K} \equiv x \bar{K}+(1-x) \bar{K}$, we obtain

$$
\mathrm{NPV} \geq 0 \Leftrightarrow \frac{Z}{r}+\frac{d}{r}-x \bar{K}-(1-x) \bar{K} \geq 0 .
$$

With $d / r \equiv(1-\tilde{x}) d / r+\widetilde{x} d / r$, we can write

$\mathrm{NPV} \geq 0 \Leftrightarrow \frac{z}{r}+(1-\tilde{x}) \frac{d}{r}+\tilde{x} \frac{d}{r}-x \bar{K}-(1-x) \bar{K} \geq 0$.

After rearranging terms we obtain

$$
\mathrm{NPV} \geq 0 \Leftrightarrow \frac{Z}{r}+(1-\tilde{x}) \frac{d}{r}-(1-x) \bar{K} \geq 0 .
$$

The entrepreneur's participation constraint states-according to inequality (1) - that the PV of the diverted free cash flow, $z / r$, plus the received dividend payment, $(1-\tilde{x}) d / r$, must not be lower than the initial cash contribution, $(1-x) \bar{K}$.

There is another way to read the entrepreneur's participation constraint. Adding and subtracting $x d / r$ from inequality (1) yields

$$
\mathrm{NPV} \geq 0 \Leftrightarrow \frac{z}{r}+(1-x) \frac{d}{r}-(\tilde{x}-x) \frac{d}{r}-(1-x) \bar{K} \geq 0 .
$$




\section{THE LIMITED PARTNERSHIP- A NUMERICAL EXAMPLE}

Assume the following values for the exogenous variables in the limited partnership:

$$
\bar{K}=100 ; w=70 ; r=0.1 ; \kappa=0.4 .
$$

Note that the project has positive NPV:

$$
\frac{y}{r}-\bar{K} \equiv \frac{(1+\kappa) r \bar{K}}{r}-\bar{K}=140-100=40>0 .
$$

If the entrepreneur invests all his initial wealth, the fraction of equity provided by the outsider reads

$$
x \equiv \frac{\bar{K}-w}{\bar{K}}=0.3 .
$$

Factoring in the equity discount, the outsider is assigned the following fraction of voting stock:

$$
\tilde{x} \equiv(1+r) x=0.33 .
$$

Dividend payments per fiscal year amount to

$$
d \equiv \frac{r \bar{K}}{1+r}=\frac{0.1 \cdot 100}{1.1}=9 . \overline{09} \text {. }
$$

The entrepreneur diverts the following amount into private accounts at the end of every fiscal year:

$$
z \equiv y-d=14-\frac{10}{1.1}=4 . \overline{90}
$$

The outside equity constraint is fulfilled because the entrepreneur's initial wealth exceeds the equity discount granted the outsider:

$$
0.7=\frac{w}{\bar{K}}>\frac{r}{1+r}=0 . \overline{09} .
$$

If (and only if) the entrepreneur's initial wealth amounts to not more than $9 . \overline{09}$ percent of the amount needed to purchase the operating assets, the outside equity constraint is violated.

The investor breaks even. The outsider's return equals the opportunity cost of capital:

$$
\frac{\tilde{x} \cdot d}{x \cdot \bar{K}}=\frac{0.33 \cdot 9 . \overline{09}}{0.3 \cdot 100}=10 \text { percent }
$$

For $\tilde{x} \equiv x(1+r)$, we can write

$$
\begin{aligned}
\mathrm{NPV} \geq 0 \Leftrightarrow & \frac{z}{r}+(1-x) \frac{d}{r}- \\
& (x[1+r]-x) \frac{d}{r}-(1-x) \bar{K} \geq 0 .
\end{aligned}
$$

After rearranging terms, we obtain

(2) NPV $\geq 0 \Leftrightarrow \frac{Z}{r}+(1-x) \frac{d}{r}-x d-(1-x) \bar{K} \geq 0$.

Inequality (2) states that the PV of the diverted free cash flow, $z l r$, plus the dividend payment on the initial capital contribution, $(1-x) d / r$, must not fall short of the sum of the capital transfer to the investor, $(\widetilde{x}-x) d l r \equiv x d$, and the initial capital contribution, $(1-x) \bar{K}$.

Outside Equity Constraint. Similar to the debt capacity constraint in debt financing, there is an outside financing constraint for equity. The constraint emerges from the entrepreneur's limited wealth. The more constrained the entrepreneur is, the higher the fraction of equity claims he has to grant the outsider. The outside equity constraint states that the fraction of equity claims held by the outsider, $\tilde{x}$, is limited to values less than one: $\tilde{x}<1$. For $\tilde{x} \equiv x(1+r)$, this inequality results in:

$$
x<\frac{1}{1+r} .
$$

With $x$ being equal to the fraction of equity injected by the outsider, we obtain

$$
\frac{\bar{K}-w}{\bar{K}}<\frac{1}{1+r} .
$$

After rearranging terms, the outside equity constraint reads

$$
\frac{w}{\bar{K}}>\frac{r}{1+r} .
$$

The inequality states that the fraction of outside equity in total liabilities must exceed a threshold that is solely determined by the marginal cost of (equity) capital. Because this condition is independent of the profitability of the project, $\kappa$, positive-NPV 
projects will not get financed if the entrepreneur's initial wealth is sufficiently low.

Optimal Level of Outside Equity Financing. As shown, the outside equity constraint sets an upper limit to the fraction of outside equity in total equity. This does not imply that the entrepreneur finances the highest fraction possible through outside equity. In fact, the entrepreneur is indifferent between investing all his initial wealth, $w$, or investing any amount $e, 0<e<w$, that satisfies the outside equity constraint. As assumed, the entrepreneur and the investor face the same opportunity cost of capital. Because the investor breaks even, there is no difference in the costs of capital to the entrepreneur with respect to outside versus inside equity.

\section{The Corporation}

The corporation may be privately held (private corporation) or publicly traded (public corporation). We start out with the private type and maintain the assumption from the partnership model that the firm outsider is a single investor (or, equivalently, a small set of block holders that act as a single investor). In a subsequent section, we compare this organizational type to the public corporation, assuming that the outsider is a multitude of small shareholders.

There are important differences between limited partnerships and corporations with regard to the outside equity holder's control rights. First, while in the limited partnership the investor can withdraw his funds at the end of the fiscal year, in the corporation the investor can pull his funds only if he has command over the majority of votes that is necessary for liquidation. ${ }^{8}$ This is because shareholders cannot sell in the aggregate, even though they can trade shares with each other. Consequently, in the corporation, minority investors are "locked in," which makes them vulnerable to opportunistic behavior by the entrepreneur. Second, unlike the limited partnership, the corporation enables the outside investor - if he has command over the necessary majority of votes - to remove the entrepreneur from the firm at the annual, end-of-fiscal-year shareholder meeting.

Note that, as in the partnership model, the optimal outcome demands the entrepreneur to be in control of the operations. Also, liquidation (in full or in part) is generally suboptimal because the going concern value always exceeds the liquidation value.

The distribution of voting rights influences the balance of power between insider and outsider when bargaining over the free cash flow at the end of the fiscal year. In the following we look at two cases of voting rights distribution, one in which the outsider has command over a simple majority of votes, and one in which the entrepreneur holds the majority. (We exclude the borderline case of each party holding 50 percent of the votes.) The outcome of this bargaining process determines the dividend payments, which in turn determines the firm's outside equity financing capacity.

\section{Dividends and Allocation of Voting Rights.} In the case where the investor holds the majority of votes, the outsider has the power to remove the entrepreneur from the firm or, equivalently, liquidate the firm. ${ }^{9}$ On the other hand, the entrepreneur has the power to refuse to contribute his human capital to the firm henceforth. Any of these two non-cooperative actions by the investor or the entrepreneur would reduce the PV of next fiscal year's free cash flow from $(1+\kappa) r \bar{K} /(1+r)$ to $r \bar{K} /(1+r)$, with the fraction $\tilde{x}$ going to the investor and the fraction $1-\tilde{x}$ going to the entrepreneur. Moreover, we assume that, if the entrepreneur were removed (at the end of the fiscal year), the entrepreneur would have no incentive to pay dividends for the current fiscal year. Because cash flows are not verifiable, the entrepreneur would divert all of the fiscal year's free cash flow into personal accounts before leaving.

Nevertheless, the parties have an incentive to cooperate because cooperation generates a surplus that the parties can share. The cooperative outcome may be modeled as a Nash bargaining solution. In a Nash bargaining solution, each party is assigned the same degree of bargaining power, and thus they share the surplus from cooperation evenly. In fact, each party receives what it would receive if the parties did not cooperate plus half the gains from cooperation. ${ }^{10}$

The surplus from cooperation at the end of the fiscal year equals the PV of the entrepreneur's value added in the next fiscal year, $(\kappa r \bar{K}) /(1+r)$. In sharing the surplus evenly, the entrepreneur pays out

\footnotetext{
8 We assume that there is no supermajority rule in place, which means that all decisions are made with a simple majority.

9 Removing the entrepreneur from the firm would result in a PV of continuation of zero, which is equivalent to liquidation.

${ }^{10}$ For details on the Nash bargaining solution, see Dagan, Volij, and Winter (2000). For a textbook example of a Nash bargaining solution in a corporate finance context, see Hart (1995).
} 
$\kappa r \bar{K} /(2(1+r))$ to the investor, in addition to what the investor would receive in the noncooperative outcome, $\tilde{x} r \bar{K} /(1+r) .{ }^{11}$ Consequently, the firm's total dividend payment equals

$$
\frac{\kappa r \bar{K}}{1+r}+\frac{r \bar{K}}{1+r}=\frac{(1+\kappa) r \bar{K}}{1+r} .
$$

Note that the dividend payment equals the PV of the free cash flow of the next fiscal year. This implies the following for the amount, $Z$, that the entrepreneur diverts for personal use:

$$
\begin{aligned}
& Z=(1+\kappa) r \bar{K}-\frac{(1+\kappa) r \bar{K}}{1+r} \\
\Leftrightarrow & \frac{Z}{r}=\frac{(1+\kappa) r \bar{K}}{1+r} .
\end{aligned}
$$

In the case where the entrepreneur holds the majority of votes, the outsider has no bargaining power once he is invested. Because the investor has no ex post bargaining power, the entrepreneur has no incentive to pay dividends. Thus, an initial private equity offering in which less than 50 percent (plus one vote) of the shares are up for sale will fail. (The entrepreneur would have to offer the shares for free, which raises no funds.)

Investor's Participation Constraint. The (outside) investor expends the amount $x \bar{K}$ at the inception of the project and receives a dividend payment equal to $r \bar{K}(\kappa+2 \widetilde{x}) /(2(1+r))$. Thus, the investor's participation constraint reads

$$
r x \bar{K} \leq \frac{r \bar{K}(\kappa+2 \tilde{x})}{2(1+r)} .
$$

Let $\delta /(1+\delta), \delta>-1$, be the percentage discount (or premium, if negative) at which the entrepreneur issues the equity to the outsider; then we can write the investor's participation constraint as follows:

$$
r x \bar{K} \leq \frac{r \bar{K}(\kappa+2 x[1+\delta])}{2(1+r)} .
$$

Rearranging terms yields

$$
\delta \geq r-\frac{\kappa}{2 x} .
$$

The entrepreneur's participation constraint is subject to $1>\widetilde{x} \equiv x(1+\delta)>1 / 2$, which demands that the outside investor holds more than 50 percent of the voting stock. Remember that the entrepreneur chooses the discount (premium) such that the investor merely breaks even or, in other words, such that the outsider's participation constraint is satisfied at equality.

Because the fraction of equity held by the entrepreneur, $1-\widetilde{x}$, can be zero, there is no upper bound on $\delta$; this means that, for any $1 \geq \tilde{x} \equiv x(1+\delta)$ $>1 / 2$, there is a value $\delta>-1$ at which the investor breaks even. We assume that the entrepreneur can divert any excess amount raised in the private equity offering, which is analogous to our assumption that the entrepreneur can divert free cash flow.

Note that there is a lower bound on the equity discount: $\delta>-1$. The fraction of capital injected by the investor, $x$, must be positive and so must be the fraction of (voting) equity that emanates from this initial capital contribution, $\tilde{x}$.

Entrepreneur's Participation Constraint. The entrepreneur expends the amount $(1-x) \bar{K}$ at inception of the project, receives periodic dividend payments equal to

$$
\frac{(1-\tilde{x}) r \bar{K}}{1+r}+\frac{\kappa r \bar{K}}{2(1+r)},
$$

and can divert the amount $(1+\kappa) r^{2} \bar{K} /(1+r)$ into personal accounts at the end of every fiscal year. Thus, the entrepreneur's participation constraint reads

$$
\frac{(1+\kappa) r \bar{K}}{1+r}+\frac{(1-\tilde{x}) \bar{K}}{1+r}-\frac{\kappa \bar{K}}{2(1+r)}+(1-x) \bar{K} \geq 0 .
$$

Substituting $x(1+\delta)$ for $\tilde{x}$ yields

$$
\delta \leq \frac{\kappa\left(r+\frac{1}{2}\right)}{x}+r .
$$

As with the investor's participation constraint discussed in the preceding section, the entrepreneur's participation constraint is subject to $1>\widetilde{x} \equiv x(1+\delta)$ $>1 / 2$, which demands that the outside investor holds more than 50 percent of the voting stock.

Outside Equity Constraint. The entrepreneur's limited wealth imposes an outside equity constraint on the firm. It is this constraint that necessitates outside equity and-at the same time-may impose an upper bound on the fraction of outside equity in total liabilities. The outside equity constraint states that the fraction of equity claims held by the outsider, $\widetilde{x}$, must not exceed unity: $\widetilde{x} \leq 1$. For $\widetilde{x} \equiv x(1+\delta)$, this inequality results in

\footnotetext{
${ }^{11}$ Note that this outcome fulfills the investor's continuation constraint by exceeding the opportunity cost of capital.
} 


$$
x \leq \frac{1}{1+\delta} .
$$

From the discussion of the investor's participation constraint, we know that the outsider breaks even, which implies the following equality for the percentage by which the fraction of equity claims held by the outsider, $\tilde{x}$, exceeds the fraction of the equity capital contributed by the outsider, $x$ :

$$
\delta=r-\frac{\kappa}{2 x} .
$$

Inserting the right-hand-side expression into the above inequality yields

$$
x \leq \frac{1}{1+r-\frac{\kappa}{2 x}} .
$$

With $x$ being equal to the fraction of capital injected by the outsider, $(\bar{K}-\mathcal{w}) / \bar{K}$, we obtain

$$
\frac{\bar{K}-w}{\bar{K}} \leq \frac{1+\frac{\kappa}{2}}{1+r} .
$$

After rearranging terms, the outside equity constraint reads

$$
\frac{w}{\bar{K}} \geq \frac{r-\frac{\kappa}{2}}{1+r} .
$$

entrepreneur anticipates the investor's ex post bargaining power and issues the equity at the lowest discount (or highest premium) that fulfills the investor's participation constraint. Thus, if the project gets financed, the entrepreneur reaps all the NPV. Also, if the project gets financed, the NPV is independent of the choice of the legal form. Consequently, the entrepreneur is indifferent about the legal form if (and only if) this decision is inconsequential to whether the project gets financed.

The only reason why a project of positive NPV might not get financed is the entrepreneur's insufficient initial wealth, $w$. In the limited partnership, the outside equity constraint (subject to the investor's participation constraint being satisfied) reads

$$
\frac{w}{\bar{K}}>\frac{r}{1+r} \text {. }
$$

Inequality (3) states that the entrepreneur has to finance more than the fraction $w / \bar{K}$ of the project's initial expenses, $\bar{K}$, through initial wealth. The threshold level $r /(r+1)$ is solely determined by the opportunity costs of capital, $r$.

In the (private) corporation, the outside equity constraint is given by

$$
\frac{w}{\bar{K}} \geq \frac{r-\frac{\kappa}{2}}{1+r} .
$$

Inequality (4) demands that the ratio of the entrepreneur's initial wealth, $w$, to the initial expenses needed to launch the project, $\bar{K}$, must meet a threshold level that is determined by the opportunity cost of capital, $r$, and the profitability of the project, $\kappa$.

Comparing the constraints across legal forms shows that the outside equity constraint is more restrictive in the limited partnership model than in the private corporation. This is because, in the private corporation, the ex post bargaining power of the investor at the end of every fiscal year allows him to capture - in a Nash bargaining solution — half the value added of the upcoming fiscal year. For a sufficiently profitable project, i.e., $\kappa \geq 2 r$, the outside equity constraint never binds in the corporation model. Remember that the outside equity constraint in the limited partnership model is independent of the project's profitability.

\section{Going Public}

We now analyze the public corporation. In finance literature, the term public corporation side investor cannot do better than break even. The 


\section{THE PRIVATE CORPORATION- FOUR NUMERICAL EXAMPLES}

We assume the same set of values for the exogenous variables of the private corporation as we did in the numerical example for the limited partnership:

$$
\bar{K}=100 ; w=70 ; r=0.1 ; \kappa=0.4 .
$$

As established for the limited partnership, the project has positive NPV. This is because the project returns exceed the opportunity cost of capital by the factor $\kappa=40$ percent. As in the partnership, the outsider has to contribute at least the fraction $x \equiv(\bar{K}-w) / \bar{K}=0.3$ to the firm's equity capital.

An important difference of the private corporation to the limited partnership is the constraint $\widetilde{x} \equiv(1+\delta) x>1 / 2$, which demands that the outsider holds the majority of votes. This condition restricts the entrepreneur in his choice of $x$ (the fraction of capital contributed by the outsider) and $\delta /(1+\delta)$ (the equity discount). For instance, assume that the entrepreneur contributes $1-x=0.7$ to the firm's capital, just as in the numerical example for the limited partnership. The value of $\delta$ at which the outsider breaks even would then read

$$
\delta=r-\frac{\kappa}{2 x}=-0.5 \overline{6} .
$$

This would mean that the outside equity is issued at a discount equal to $\delta /(1+\delta) \approx-1.31$, or in other words, at a premium of about 131 percent. At this premium, though, the outside investor would not have command over the majority of votes:

$$
0.13=x \cdot(1+\delta) \equiv \tilde{x}<\frac{1}{2} .
$$

Consequently, the entrepreneur chooses to contribute a lower fraction to the firm's equity than what he is able to. For instance, the entrepreneur might contribute the fraction $1-x=0.1$ only.

For $1-x=0.1$, the value of $\delta$ at which the outsider breaks even, reads

$$
\delta=r-\frac{\kappa}{2 x}=-0.1 \overline{2} .
$$

This would mean that the outside equity is issued at a discount equal to $\delta /(1+\delta) \approx-0.14$, or, in other words, at a premium of approximately 14 percent. The outsider would end up with $\widetilde{x} \equiv$ $(1+\delta) \cdot x=79$ percent of the voting stock.

The dividend payment amounts to

$$
d \equiv \frac{(1+\kappa) r \bar{K}}{1+r}=\frac{1.4 \cdot 0.1 \cdot 100}{1.1}=12 . \overline{72} .
$$

The amount that the entrepreneur diverts into personal accounts equals

$$
z \equiv y-d=14-12 . \overline{72}=1 . \overline{27} .
$$

The outside investor breaks even:

$$
\begin{aligned}
9 & =0.1 \cdot 0.9 \cdot 100=r x \bar{K} \\
& =\frac{r \bar{K}(\kappa+2 x[1+\delta])}{2(1+r)} \\
& =\frac{0.1 \cdot 100 \cdot(0.4+2 \cdot 0.9 \cdot[1-0.1 \overline{2}])}{2 \cdot 1.1}=9 .
\end{aligned}
$$

The outside equity constraint is fulfilled:

$$
0.3=\frac{w}{\bar{K}} \geq \frac{r-\frac{\kappa}{2}}{1+r}=-0 . \overline{09} .
$$

Because the project is sufficiently profitable, the outside equity constraint never binds. For $\kappa \geq 2 r$ the entrepreneur is able to attract outside equity without contributing his own capital. This is in sharp contrast to the numerical example of the limited partnership, where the entrepreneur has to contribute more than $9 . \overline{09}$ percent of the initial capital expenditure.

The outside equity constraint is relevant only if the project is not sufficiently profitable, i.e., if $\kappa<2 r$. Even in this case, the outside equity constraint is less restrictive than in the limited partnership. For instance, in the partnership the project cannot be financed if the entrepreneur's wealth, $w$, amounts to less than $9 . \overline{09}$. In the private corporation, though, the entrepreneur can attract outside equity for a project with low profitability $\kappa=0.1$ even if his wealth is as low as $w=4 . \overline{54}$. The entrepreneur would issue the equity at a discount of $4 . \overline{54}$, granting the outsider $\widetilde{x}=100$ of the voting capital. 
represents listed companies with dispersed shareholder structures.

Dispersed shareholders face high costs of collective action. These costs restrain the bargaining power the shareholders have once they are invested. We assume that if (and only if) the dividend payments fall short of the opportunity cost of capital, the shareholders remove the entrepreneur from the corporation or, equivalently, liquidate the project. Note that without this assumption, the entrepreneur pays no dividends.

Investor's Continuation Constraint. As with the private corporation, outside equity financing is possible only if the outside shareholders have command over a majority of votes: $\widetilde{x}>1 / 2$. Without a majority of votes, the investor cannot liquidate, and, consequently, the entrepreneur has no incentive to pay dividends.

In the event of liquidation, the shareholders can withdraw their fraction of assets. Thus, the continuation constraint reads

$$
\tilde{x} d \geq \tilde{x} \frac{r \bar{K}}{1+r} .
$$

This continuation constraint is equivalent to the continuation constraint in the partnership model.

Investor's Participation Constraint. Subject to $\tilde{x}>1 / 2$, the (outside) investor's participation constraint reads

$$
r x \bar{K} \leq \tilde{x} d\left[=\tilde{x} \frac{r \bar{K}}{1+r}\right] .
$$

Except for the condition $\tilde{x}>1 / 2$, this participation constraint is identical to the investor's participation constraint in the partnership model.

Entrepreneur's Participation Constraint. Under the assumption of competitive capital markets, the investor breaks even, which implies that the investor's participation constraint is fulfilled at equality. For the investor to break even, the entrepreneur has to issue the outside equity at a discount:

$$
\tilde{x}=x(1+r) .
$$

Because the investor does not do better than break even, the entrepreneur reaps the whole (positive) NPV, which implies that the entrepreneur's participation constraint is satisfied.

Equivalence of Legal Forms. In summary, the public corporation model is equivalent to the partnership model when the constraint $\tilde{x}>1 / 2$ is added and the outside equity constraint is allowed to hold at equality:

\section{Table 1}

\section{Outside Equity Constraints}

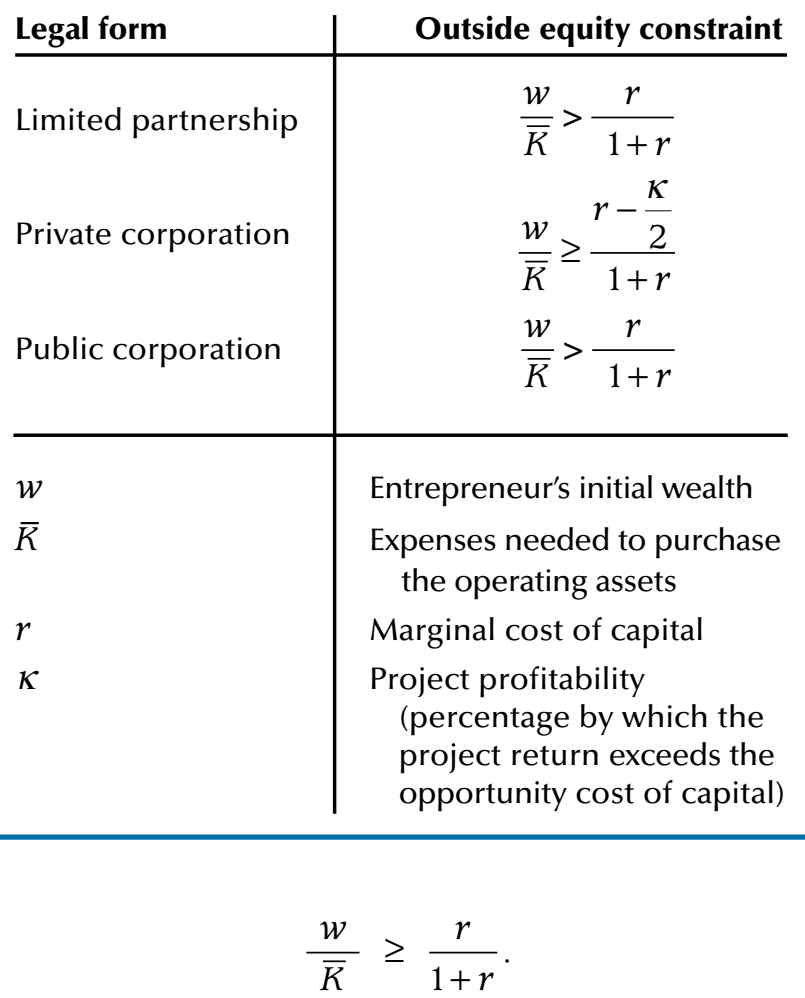

In contrast to the limited partnership, the wealth of the entrepreneur in the corporation may adopt a value of zero.

For the constraint $\tilde{x}>1 / 2$, which demands the outsider to hold the majority of votes, we obtain the following after rearranging terms:

$$
\frac{w}{\bar{K}}<\frac{\frac{1}{2}+r}{1+r} .
$$

This constraint never binds, because the entrepreneur can choose to invest only the amount $e \leq w$ of his wealth.

The outside equity constraints of all three legal forms are summarized in Table 1.

\section{CONCLUSION}

In this article we analyzed outside equity financing of the entrepreneurial firm when cash flows are non-verifiable. The study covered three legal forms: the limited partnership, the private corporation, and the public corporation. We showed that the limited partnership and the public corporation are equivalent with regard to the outside investor's 
bargaining power once he is invested. Of the three analyzed legal forms, the private corporation renders the most ex post bargaining power to the outside investor. Consequently, when organizing the project into a private corporation, the entrepreneur faces the least restrictive outside equity constraint. This is because the outside investors in the private corporation are block holders whose costs of collective action are low. The block holders have the power to remove the entrepreneur from his post (or, equivalently, liquidate the firm). Clearly, this presupposes that the outsiders hold the majority of votes. If outside equity holds a minority interest in the corporation, the insider has no incentive to pay dividends and will divert all free cash flow for personal use.

The article underlines the importance of venture capital financing. Venture capital allows positive-NPV projects that are organized into private corporations to be financed even when the entrepreneur is strongly wealth-constrained. For less wealthconstrained entrepreneurs, the three legal types are equivalent. If the entrepreneur's wealth is sufficiently low, however, positive-NPV projects cannot be financed in either legal form. This is because of the entrepreneur's inability to commit to a level of dividend payments that allows the outside investor to break even.

\section{REFERENCES}

Dagan, Nir; Volij, Oscar and Winter, Eyal. "A Characterization of the Nash Bargaining Solution." Unpublished manuscript, Brown University, Washington University, and Hebrew University, 2000, < http://www.nirdagan.com/research/> .

Grossman, Sanford J. and Hart, Oliver D. "One Share-One Vote and the Market for Corporate Control." Journal of Financial Economics, January/March 1988, 20(1/2), pp. 175-202.
Harris, Milton and Raviv, Artur. "Corporate Governance: Voting Rights and Majority Rules.” Journal of Financial Economics, January/March 1988, 20(1/2), pp. 203-35.

Hart, Oliver. Firms, Contracts, and Financial Structure. New York: Clarendon Press, 1995.

Jensen, Michael C. A Theory of the Firm: Governance, Residual Claims, and Organizational Forms. Cambridge, MA: Harvard University Press, 2000.

and Meckling, William H. "Theory of the Firm: Managerial Behavior, Agency Costs, and Capital Structure." Journal of Financial Economics, October 1976, 3(4), pp. 305-60.

Kirilenko, Andrei A. "Valuation and Control in Venture Finance.” Journal of Finance, April 2001, 56(2), pp. 565-87.

McConnell, John J. and Servaes, Henri. "Additional Evidence on Equity Ownership and Corporate Value." Journal of Financial Economics, October 1990, 27(2), pp. 595-612.

Milgrom, Paul and Roberts, John. Economics, Organization, and Management. Englewood Cliffs, NJ: Prentice-Hall, 1992.

Morck, Randall; Shleifer, Andrei and Vishny, Robert. "Management Ownership and Market Valuation: An Empirical Analysis." Journal of Financial Economics, January/March 1988, 20(1/2), pp. 293-315.

Myers, Stewart C. "Outside Equity.” Journal of Finance, June 2000, 55(3), pp. 1005-37.

Zingales, Luigi. "In Search of New Foundations." Journal of Finance, August 2000, 55(4), pp. 1623-53.

Zwiebel, Jeffrey. "Dynamic Capital Structure Under Managerial Entrenchment." American Economic Review, December 1996, 86(5), pp. 1197-215. 


\section{Appendix}

Is the partnership contract renegotiation-proof, or does the investor have an incentive to demand renegotiation of the contract by threatening to withdraw his funds?

If at the end of the first fiscal year the investor threatens to withdraw his funds, the entrepreneur has the option of not making the last dividend payment and substituting (renegotiation-free) debt for equity by issuing an infinitely lived bond, a console. The console would have a par value equal to $\tilde{x} \bar{K}$ and sell for $x \bar{K}$. The periodic, annual interest payment would amount to $\tilde{x} d$. If the entrepreneur defaults on servicing the console, the assets transfer to the debt holder either entirely (total liquidation, undertaken by the investor) or partially (partial liquidation, undertaken by the entrepreneur). Because the operating assets are worth more in the project than outside, the entrepreneur has an incentive to make the agreed-upon payments. On the other hand, the entrepreneur's ability to substitute a console for outside equity implies that the limited partner has no bargaining power when trying to renegotiate the partnership contract. Thus the partnership contract is renegotiationfree, which in turn implies that outside equity is equivalent to debt. 
REVIEW

28 NOVEMBER/DECEMBER 2001 